\title{
Langvarige korsryggssmerter og MR-forandringer i ryggvirvlene
}

\author{
Sammendrag \\ Bakgrunn. Selv om korsryggssmerter \\ som oftest går over av seg selv, blir en \\ del pasienter ikke bedre og trenger \\ behandling. Det er derfor viktig å klar- \\ gjøre hvilke forhold som bidrar til \\ smertene. Vi gir her en oversikt over \\ ny forskning omkring MR-funn og \\ genetiske forhold som kan ha betyd- \\ ning for utviklingen av langvarige kors- \\ ryggssmerter.
}

Materiale og metode. Utgangspunkt for denne oversikten er et ikke-systematisk søk i PubMed og EMBASE. Forfatternes kjennskap til feltet er bakgrunn for valg av artikler.

Resultater. Tradisjonelt har man antatt at korsryggssmerter ofte stammer fra mellomvirvelskiver, fasettledd og lumbale ryggmuskler. Men det har også lenge vært kjent at mange pasienter med fremtredende skivedegenerasjon har såkalte Modic-forandringer, dvs. $M R$-forandringer i beinmargen ved ryggvirvlenes endeplater. I flere nye studier er det påvist en sammenheng mellom slike forandringer og smerte. Det er også vist at pasienter med Modic-forandringer og korsryggssmerter ofte har en pågående lokal inflammasjonstilstand, med innvekst av smertefibre i endeplatene. I hvilken grad dette skjer, kan være delvis genetisk betinget.

Fortolkning. Genetiske faktorer kan bidra til korsryggssmerter. Mer kunnskap om genetikk og Modic-forandringer kan danne grunnlag for bedre diagnostikk og mer spesifikk behandling av pasienter med langvarige korsryggssmerter.

\author{
Ellina lordanova \\ Cecilie Røe \\ Anne Keller \\ Avdeling for fysikalsk medisin og rehabilitering \\ Oslo universitetssykehus, Ullevål
}

\section{Jan Sture Skouen}

Avdeling for fysikalsk medisin og rehabilitering Haukeland universitetssykehus

Regionalt kompetansesenter for habilitering og rehabilitering i Helse Vest

Helse Bergen

\section{Lars Jørgen Rygh}

Kirurgisk serviceklinikk

Haukeland universitetssykehus

\section{Ansgar Espeland}

Radiologisk avdeling

Haukeland universitetssykehus

Seksjon for radiologi

Institutt for kirurgiske fag

Universitetet i Bergen

\section{Johannes Gjerstad}

johannes.gjerstad@stami.no

Avdeling for muskel-skjelettlidelser

Statens arbeidsmiljøinstitutt

Postboks 8149 Dep

0033 Oslo

og

Institutt for molekylær biovitenskap

Universitetet i Oslo

Langvarig smerte et stort problem både $\mathrm{i}$ Norge og andre vestlige land (1). Korsryggssmerter er særlig utbredt. Dette fører til nedsatt livskvalitet for dem som rammes og betydelige økonomiske kostnader for samfunnet $\mathrm{i}$ form av trygdeutgifter.

Tidligere studier viser at korsryggssmerter kan være assosiert med fysiske arbeidsfaktorer, f.eks. løft med vridning eller helkroppsvibrasjon (2), samt kombinasjonen tungt fysisk arbeid og røyking (3). Ny kunnskap tyder imidlertid på at grad og varighet av korsryggssmerter også har sammenheng med individuell genetisk sårbarhet (4).

Ryggsmerter inndeles vanligvis i følgende diagnosekategorier: uspesifikke korsryggssmerter (80-90\%), korsryggssmerter med nerverotsaffeksjon (5-10\%) og korsryggssmerter med mulig underliggende alvorlige patologiske forandringer $(1-5 \%)$ $(5,6)$.

Denne artikkelen dreier seg om første og annen kategori og gir en oversikt over ny forskning på MR-funn og genetiske forhold av betydning for utvikling av langvarige korsryggssmerter.

\section{Materiale og metode}

Det ble gjort et ikke-systematisk søk i PubMed og EMBASE. Et skjønnsmessig utvalg av originalartikler samt forfatternes kjennskap til feltet danner grunnlaget for denne oversikten.

\section{Skivedegenerasjon og forandringer i vevet rundt}

Korsryggssmerter synes ofte å stamme fra mellomvirvelskiver, fasettledd og lumbale multifundimuskler. Spesielt skivedegenerasjon, som er assosiert med innvekst av perifere nervefibre i skiven (7), synes å være forbundet med korsryggssmerter (8). Skivedegenerasjon defineres som strukturelle forandringer i mellomvirvelskiven og ses på MR som annulusruptur, høyintensitetssone (high intensity zone, HIZ), skivehøydereduksjon og forandringer i skivekontur som buking, protrusjon, ekstrusjon og sekvestrering $(9-11)$.

Når korsryggssmertene er kombinert med utstråling, har man tradisjonelt antatt at patogenesen omfatter både mekanisk trykk på de perifere nerverøttene og kjemisk nervepåvirkning. Det er også kjent at mange pasienter med fremtredende skivedegenerasjon har forandringer i beinmargen inntil ryggvirvlenes endeplater som er synlige på MR (12). Forandringer ved endeplatene oppstår hos ca. 40 \% av dem med degenerative mellomvirvelskiver og kalles Modicforandringer (13). Sammenhengen mellom Modic-forandringer og smerte er nylig undersøkt i flere studier $(11,14)$. Selv om disse forandringene også finnes hos ca. $5 \%$ av friske uten korsryggssmerter (13), indikerer resultatene fra disse arbeidene $(11,14)$ at slike forandringer kan være viktigere for smerteutviklingen enn tidligere antatt.

\section{Hovedbudskap}

- Modic-forandringer er assosiert med utvikling av langvarige ryggsmerter

- Flere genvarianter kan tenkes å bidra til Modic-forandringer

- Modic-forandringer er også assosiert med nervevekst inn i ryggvirvlenes endeplater

- Kunnskap om disse forandringene kan danne grunnlag for ny behandling 
Modic-forandringer observert på MR Modic-forandringer, først beskrevet i 1988 av den amerikanske radiologen Modic, defineres som forandringer i endeplater og tilstøtende beinmarg verifisert på MR (15). Slike forandringer er assosiert med skivedegenerasjon der den degenerative prosessen også omfatter endringer i endeplater og tilstøtende beinmarg i virvelcorpora.

Modic-forandringer deles inn i tre kategorier/stadier (12). Modic type 1-forandringer (hypointense på T1-vektede og hyperintense på T2-vektede MR-bilder) representerer histopatologisk sett fissurerte endeplater, vaskularisert fibrøst vev i tilstøtende beinmarg og ødemer (fig 1). Modic type 2-forandringer (hyperintense på T1-vektede og isointense eller hyperintense på T2-vektede MRbilder) representerer fissurerte endeplater og fettavleiring i subkondral beinmarg. Modic type 3-forandringer (hypointense både på T1- og T2-vektede MR-bilder) representerer subkondral beinsklerose.

Stigning av nivået av høysensitivt C-reaktivt protein (hsCRP) hos pasienter med korsryggsmerter og Modic type 1-forandringer tyder på lokal inflammasjon i vertebrale endeplater (16). Tilsvarende er ikke vist for Modic-forandring av type 2 og type 3. Likevel er det nå klart at subkondral beinsklerose er til stede ved alle typer Modic-forandringer, spesielt ved blandede typer $1-2$ og 2-3, og ikke bare ved type 3 , som tidligere antatt (17). Flere ferske studier $(18-20)$ har demonstrert at Modic-klassifikasjonen er reliabel og kan anvendes konsistent i forskning og klinisk/radiologisk praksis.

De ulike Modic-typene er antatt å representere ulike stadier av samme patologiske prosess. Modic-forandringer kan konvertere fra en type til en annen, mest vanlig fra type 1 til type 2 . Type 1 kan også reverseres til normal variant, mens type 2 er mer stabil (12). Noen ganger vil likevel type 2 konvertere til type 3. Ytre påvirkning, f.eks. injeksjon av kymopapain (proteinspaltende enzym fra papayafrukt) eller kirurgisk behandling, kan medvirke til utvikling av Modicforandringer $(12,21)$. Slike forandringer er oftest lokalisert i nivåene L4/L5 og L5/S1.

\section{Patofysiologiske mekanismer}

Det omtales i litteraturen minst to mulige patofysiologiske mekanismer for utvikling av Modic-forandringer (9). Én hypotese er at forandringene er et resultat av lokal inflammasjon og ødemer som følger med lavgradig infeksjon. Dette forutsetter ruptur av annulusfibrene samt danning av nye kapillarer rundt ekstrudert nucleus pulposus, som gjør det mulig for anaerobe bakterier å migrere til mellomvirvelskiven via rupturen i annulusfibrene. I en nyere studie med 24 pasienter med Modic type 1-forandringer fant man imidlertid ingen oppvekst av anaerobe bakterier (22).

En annen hypotese er at Modic-forandringer er forårsaket av skivedegenerasjon, dvs. danning av mikrofrakturer i skiven, reduk- sjon i skivehøyde og senket hydrostatisk skivetrykk samt økte skjærende krefter på endeplatene ved mekanisk belastning. I så fall er utviklingen av Modic-forandringene igangsatt av redusert støtdemping og vevsskade, forsterket ved frisetting av proinflammatoriske nevrotoksiske stoffer fra nucleus pulposus som påvirker endeplatene via mikrofrakturene. Dette gir lokal inflammasjon og ødemer.

Siden det foreløpig er uavklart om patogenesen for utvikling av Modic-forandringer kan være bakteriell, omtales videre bare den antatte ikke-bakterielle inflammasjonen rundt skiven.

\section{Inflammasjon rundt mellomvirvelskiven}

Tidligere pasientstudier viser at det ved skiveherniering frisettes en rekke proinflammatoriske stoffer, bl.a. prostaglandiner, bradykinin, nitrogenoksid (NO), tumornekrose- faktor- $\alpha$ (TNF- $\alpha$ ), interleukin 1- $\beta$ (IL-1- $\beta$ ), interleukin 6 (IL-6) (23) samt metalloproteaser (24). Disse stoffene vil aktivere nociseptorene, men også fremme videre skivedegenerasjon. Videre viser dyrestudier at stoffer fra nucleus pulposus kan indusere funksjonelle nerverotsabnormaliteter, f.eks. redusert nerveledningshastighet (25). Stoffene kan altså ha en toksisk effekt på nerverøttene. Effekten er sannsynligvis mediert av strukturer på overflaten av nucleus pulposus-cellene, som er immunogene.

Det er derfor holdepunkter for å anta at pasienter med økt tendens til inflammasjon og forandringer i beinmargen ved de vertebrale endeplatene også har økt tendens til å utvikle langvarig ryggsmerte. Ny forskning støtter en slik oppfatning $(11,14)$. Dataene fra disse arbeidene viser at det trolig er en sammenheng mellom symptomene og de strukturelle forandringene. Spesielt gjelder dette Modic type 1-forandringer i L5/S1-nivå.

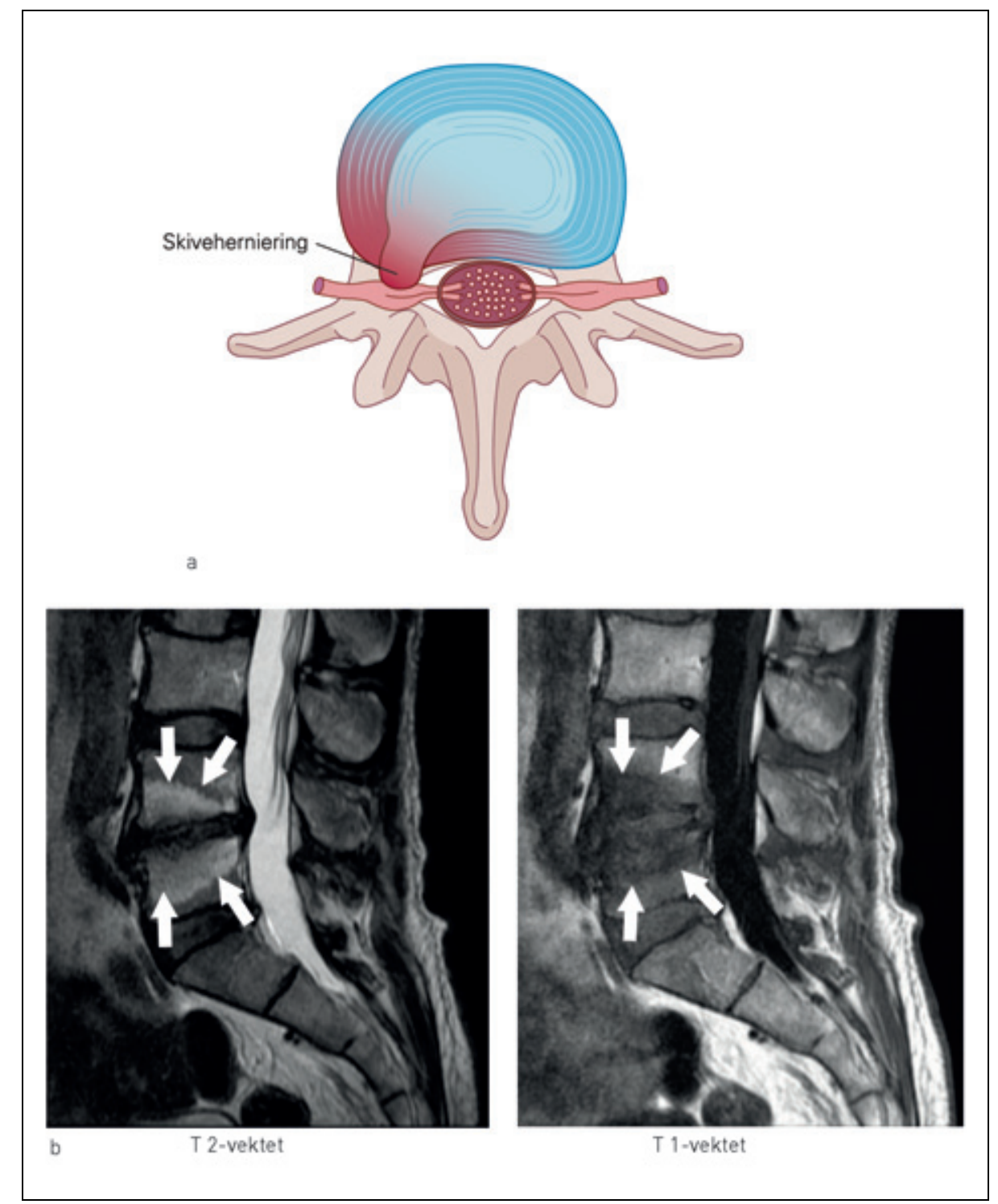

Figur 1 a) Skiveherniering. Når skiven hernierer, frisettes en rekke proinflammatoriske stoffer som påvirker de omkringliggende strukturene. b) Modic-forandringer (her type 1) er assosiert med skivedegenerasjon der den degenerative prosessen også har begynt å affisere endeplater og tilstøtende beinmarg i virvelcorpora. Foto Oslo universitetssykehus, Ullevål 


\section{Vekst av nervefibre inn i virvlene}

Dyrestudier har vist at TNF- $\alpha$ og IL-1- $\beta$ gir en betydelig økning i frisettingen av nervevekstfaktor (NGF), som igjen gir nye forgreninger (sprouting) $(26,27)$ av perifere nervefibre (fig 2). I tillegg er det nylig vist at de vertebrale endeplatene hos pasienter med Modic type 1- eller type 2-forandringer inneholder mer TNF- $\alpha$-immunreaktive celler enn hos individer med normale endeplater (28). Det er derfor sannsynlig at TNF- $\alpha$ og IL-1- $\beta$ kan gi nye forgreninger og innvekst av nervefibre i de vertebrale endeplatene. Dette gjelder spesielt når det er en lekkasje av kondrocytter, som frisetter cytokiner fra nucleus pulposus.

Nerveinnveksten i de vertebrale endeplatene er nå også bekreftet histologisk med immunhistokjemiske metoder hos pasienter som blir operert for lumbal prolaps (28). Videre viser dataene fra både dyrestudier og pasientstudier at det er de umyeliniserte Cfibrene, altså smertefibrene, som hovedsakelig danner disse nye perifere forgreningene $(7,26-28)$. Det er derfor grunn til å anta at økt uttrykk av TNF- $\alpha$ og IL-1- $\beta$ er viktig for utviklingen av Modic-forandringer med nerveinnvekst, som antakelig også er av betydning for smerteutviklingen.

\section{Genetiske faktorer}

Mange gener finnes i flere utgaver, f.eks. en «vanlig» og en «variant». Ofte skyldes varianten at ett enkelt basepar i DNA-koden er byttet ut med et annet. Genetiske varianter kan affisere en rekke typer proteiner, deriblant cytokiner og vekstfaktorer som ligger til grunn for inflammasjon og nerveinnvekst i strukturene rundt de degenererte skivene.

Vi kjenner allerede til flere varianter av gener som koder for proinflammatoriske/nociseptive faktorer. Disse inkluderer IL-1- $\beta$, IL-6 og GTP-syklohydrolase, som også er assosiert med korsryggssmerter og isjias (29-31).

I denne prosessen kan TNF- $\alpha$ og IL-1- $\beta$, som gir økt frisetting av nervevekstfaktor, være viktige. Koblingen mellom TNF- $\alpha$, IL- $1-\beta$ og nervevekstfaktor $(26,27)$ er avgjørende for nervecellenes syntese av strukturelle proteiner, som igjen er en forutsetning for innveksten av nervefibre i de vertebrale endeplatene (28). Derfor vil trolig TNF- $\alpha$ forårsake perifer nervevekst. Men i hvilken grad den enkelte pasient får nye nerveforgreninger inn i endeplater med Modic-forandringer vil variere og er trolig betinget av både genetiske og mekaniske faktorer.

\section{Mulig ny behandling}

Nyere data viser at det er en synergistisk effekt mellom en genvariant som koder for IL-6 og tungt fysisk arbeid (29). Denne kombinasjonen synes å bidra til langvarig korsryggssmerter med utstråling. Videre er det også vist at en kombinasjon av genvarianter i gener som koder for interleukin 1- $\alpha$ (IL-1- $\alpha$ ) og metalloproteinase (MMP3), er assosiert med økt forekomst av Modic type 2-forandringer (32) samt at genvarianter som koder for vitamin D-reseptoren, er assosiert med skivedegenerasjon (33).

Mer kunnskap om dette kan etter hvert gjøre det mulig i større grad å skreddersy behandlingen til hver enkelt ryggpasient. Særlig er det viktig å frembringe mer kunnskap om hvorvidt det finnes en undergruppe pasienter med langvarige korsryggssmerter og Modic-forandringer som kan ha nytte av TNF- $\alpha$-hemmere. Tidligere data viser imidlertid at TNF- $\alpha$-hemmeren infliximab ikke har signifikant effekt på isjiaspasienter utover placebo på gruppenivå $(34,35)$. Men det at man ikke har funnet noen signifikante effekter av TNF- $\alpha$-hemmere på gruppenivå, utelukker ikke at man kan finne signifikante - og klinisk viktige - effekter av samme behandling på subgruppenivå. Derfor er det behov for mer kunnskap om genetiske faktorer, Modic-forandringer og subgruppering.

\section{Konklusjon}

Nye data viser at Modic-forandringer kan være assosiert med en pågående inflammasjonsprosess og påfølgende innvekst av smertefibre i ryggvirvlenes endeplater. Både

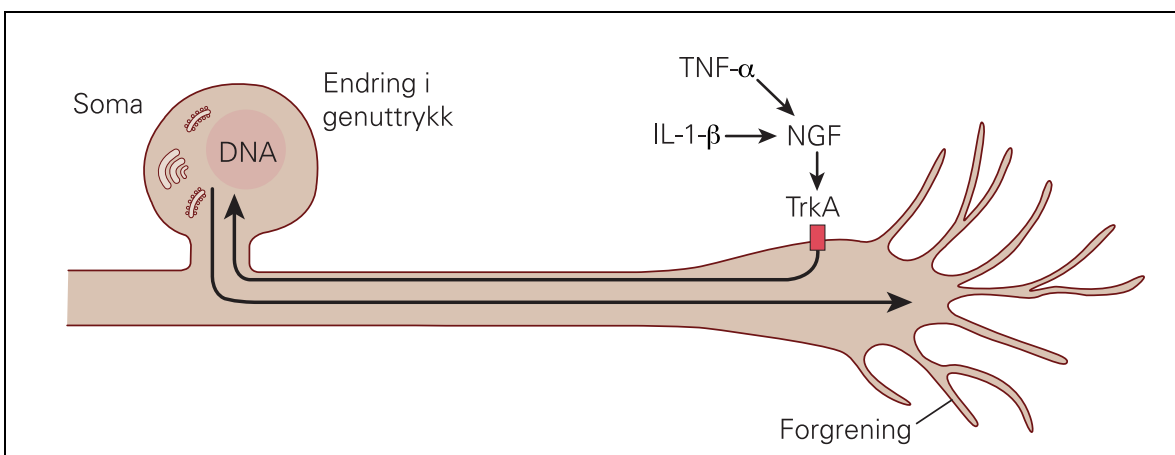

Figur 2 Forgreninger (sprouting) og nervevekst: Ved inflammasjon vil TNF- $\alpha$ og IL-1- $\beta$ øke frisettingen av nervevekstfaktor (NGF), som i sin tur bindes til TrkA-reseptorene ismertefibrene. Dermed dannes et NGF-TrkA-kompleks. Dette tas opp i smertefibrene og transporteres så til cellens soma, der nervevekstfaktoren øker genuttrykket av ulike strukturelle proteiner. Disse proteinene transporteres så ut igjen til nerveenden, der de gir opphav til nye forgreninger

inflammasjonen og andre forhold som leder til denne perifere nerveveksten er trolig delvis genetisk betinget. Mer forskning på predisponerende genetiske faktorer til disse forandringene kan danne grunnlag for bedre diagnostikk og mer spesifikk behandling av pasienter med langvarige korsryggssmerter.

Oppgitte interessekonflikter: Ingen

\section{Litteratur}

1. Breivik H, Collett B, Ventafridda V et al. Survey of chronic pain in Europe: prevalence, impact on daily life, and treatment. Eur J Pain 2006: 10 287-333.

2. Lotters F, Burdorf A, Kuiper J et al. Model for the work-relatedness of low-back pain. Scand J Work Environ Health 2003; 29: 431-40.

3. Leboeuf-Yde C, Kjaer P, Bendix T et al. Selfreported hard physical work combined with heavy smoking or overweight may result in so-called Modic changes. BMC Musculoskelet Disord 2008; 9: 5

4. Gjerstad J. Genetic susceptibility and development of chronic non-malignant back pain. Rev Neurosci 2007; 18: 83-91.

5. Lærum E, Brox J, Storheim K et al. Nasjonale kliniske retningslinjer. Korsryggsmerter - med og uten nerverotaffeksjon. Oslo: FORMI, Formidlings enheten for muskel- og skjelettlidelser/Sosial-og helsedirektoratet, 2007. www.formi.no (10.9.2007).

6. van Tulder MW, Kovacs F, Müller G et al. The European guidelines for the management of low back pain in primary care. www. backpaineurope.org (10.9.2007).

7. Freemont AJ, Peacock TE, Goupille P et al. Nerve ingrowth into diseased intervertebral disc in chronic back pain. Lancet 1997; 350: 178-81.

8. Battie MC, Videman T, Levalahti E et al. Heritability of low back pain and the role of disc degeneration. Pain 2007: 131: 272-80.

9. Albert HB, Kjaer P, Jensen TS et al. Modic changes, possible causes and relation to low back pain Med Hypotheses 2008; 70: 361-8.

10. Kjaer P, Leboeuf-Yde C, Korsholm L et al. Magnetic resonance imaging and low back pain in adults: a diagnostic imaging study of 40-year-old men and women. Spine 2005; 30: 1173-80.

11. Kjaer P, Korsholm L, Bendix T et al. Modic changes and their associations with clinical findings. Eur Spine J 2006: 15: 1312-9.

12. Modic MT, Steinberg PM, Ross JS et al. Degenerative disk disease: assessment of changes in vertebral body marrow with MR imaging. Radiology 1988: 166: 193-9.

13. Jensen TS, Karppinen J, Sorensen JS et al. Vertebral endplate signal changes (Modic change): a systematic literature review of prevalence and association with non-specific low back pain. Eur Spine J 2008; 17: 1407-22.

14. Kuisma M, Karppinen J, Niinimaki J et al. Modic changes in endplates of lumbar vertebral bodies: prevalence and association with low back and sciatic pain among middle-aged male workers. Spine 2007: 32: 1116-22

15. Fardon DF, Milette PC. Nomenclature and classification of lumbar disc pathology. Recommendations of the Combined task Forces of the North American Spine Society, American Society of Spine Radiology, and American Society of Neuroradiology. Spine 2001; 26: E93-E113.

16. Rannou F, Ouanes W, Boutron I et al. High-sensitivity $\mathrm{C}$-reactive protein in chronic low back pain with vertebral end-plate modic signal changes. Arthritis Rheum 2007; 57: 1311-5.

17. Kuisma M, Karppinen J, Haapea M et al. Modic changes in vertebral endplates: a comparison of MR imaging and multislice CT. Skeletal Radiol 2009; 38: 141-7.

18. Carrino JA, Lurie JD, Tosteson AN et al. Lumbar spine: reliability of MR imaging findings. Radiology 2009; 250: $161-70$

19. Jensen TS, Sorensen JS, Kjaer P. Intra- and interobserver reproducibility of vertebral endplate signal (modic) changes in the lumbar spine: the Nordic Modic Consensus Group classification. Acta Radiol 2007; 48: 748-54. 
20. Peterson CK, Gatterman B, Carter JC et al. Interand intraexaminer reliability in identifying and classifying degenerative marrow (Modic) changes on lumbar spine magnetic resonance scans. J Manipulative Physiol Ther 2007: 30: 85-90.

21. Vital JM, Gille O, Pointillart V et al. Course of Modic 1 six months after lumbar posterior osteosynthesis. Spine 2003; 28: 715-20.

22. Wedderkopp N, Thomsen K, Manniche C et al. No evidence for presence of bacteria in modic type I changes. Acta Radiol 2008; 50: 65-70.

23. Kang JD, Stefanovic-Racic M, McIntyre LA et al. Toward a biochemical understanding of human intervertebral disc degeneration and herniation. Contributions of nitric oxide, interleukins, prostaglandin E2, and matrix metalloproteinases. Spine 1997; 22: 1065-73.

24. Goupille P, Mulleman D, Valat JP. Radiculopathy associated with disc herniation. Ann Rheum Dis 2006; 65: 141-3

25. Brisby H, Byrod G, Olmarker K et al. Nitric oxide as a mediator of nucleus pulposus-induced effects on spinal nerve roots. J Orthop Res 2000; 18: 815-20.

26. Safieh-Garabedian B, Poole S, Allchorne A et al.
Contribution of interleukin-1 beta to the inflammation-induced increase in nerve growth factor levels and inflammatory hyperalgesia. Br J Pharmacol 1995; 115: 1265-75

27. Woolf CJ, Allchorne A, Safieh-Garabedian B et al. Cytokines, nerve growth factor and inflammatory hyperalgesia: the contribution of tumour necrosis factor alpha. Br J Pharmacol 1997; 121: 417-24.

28. Ohtori S, Inoue G, Ito T et al. Tumor necrosis factor-immunoreactive cells and PGP 9.5-immunoreactive nerve fibers in vertebral endplates of patients with discogenic low back pain and Modic type 1 or type 2 changes on MRI. Spine 2006; 31 : 1026-31.

29. Karppinen J, Daavittila I, Noponen N et al. Is the interleukin-6 haplotype a prognostic factor for sciatica? Eur J Pain 2008; 12: 1018-25.

30. Solovieva S, Leino-Arjas P, Saarela J et al. Possible association of interleukin 1 gene locus polymorphisms with low back pain. Pain 2004; 109: 8-19.

31. Tegeder I, Costigan M, Griffin RS et al. GTP cyclohydrolase and tetrahydrobiopterin regulate pain sensitivity and persistence. Nat Med 2006; 12: 1269- 77 .
32. Karppinen J, Daavittila I, Solovieva S et al. Genetic factors are associated with modic changes in endplates of lumbar vertebral bodies. Spine 2008; 33: $1236-41$.

33. Cheung KM, Chan D, Karppinen J et al. Association of the Taq I allele in vitamin D receptor with degenerative disc disease and disc bulge in a Chinese population. Spine 2006; 31: 1143-8.

34. Korhonen T, Karppinen J, Paimela $L$ et al. The treatment of disc herniation-induced sciatica with infliximab: results of a randomized, controlled, 3month follow-up study. Spine 2005; 30: 2724-8.

35. Korhonen T, Karppinen J, Paimela L et al. The treatment of disc-herniation-induced sciatica with infliximab: one-year follow-up results of FIRST II, a randomized controlled trial. Spine 2006; 31 : $2759-66$.

Manuskriptet ble mottatt 21.1. 2009 og godkjent 7.1. 2010. Medisinsk redaktør Trine B. Haugen. 